\title{
PENGETAHUAN PETANI KENTANG TERHADAP PROSEDUR PEMBIAYAAN SYARIAH DI KECAMATAN PASIRWANGI, KABUPATEN GARUT
}

\section{THE KNOWLEDGE OF POTATO FARMERS ON PROCEDURE TO OBTAIN SHARIA FINANCE IN PASIRWANGI SUBDISTRICT, GARUT DISTRICT}

\author{
Deviawati*, Eliana Wulandari \\ Program Studi Agribisnis, Fakultas Pertanian, Universitas Padjadjaran \\ Jl. Raya Bandung-Sumedang KM. 21, Jatinangor, Jawa Barat \\ *E-mail: ddeviawati@gmail.com \\ (Diterima 7-1-2021; Disetujui 18-1-2021)
}

\begin{abstract}
ABSTRAK
Kecamatan Pasirwangi merupakan salah satu sentra penghasil kentang di Kabupaten Garut. Dalam menjalankan usahatani, petani mempunyai berbagai permasalahan, salah satunya adalah permodalan. Hal tersebut terjadi karena biaya usahatani kentang relatif besar, sehingga dibutuhkan pembiayaan lain selain modal pribadi. Tujuan dari penelitian ini adalah untuk menganalisis pengetahuan petani kentang kentang terhadap prosedur untuk mendapatkan pembiayaan syariah dan faktor-faktor yang berkaitan dengan pengetahuan. Penelitian ini menggunakan metode kuantitatif. Pengumpulan data diperoleh dari 50 orang petani kentang di Kecamatan Pasirwangi, Kabupaten Garut. Metode analisis data menggunakan gap analysis dan ordinary least square. Hasil penelitian menunjukkan bahwa pengetahuan petani terhadap prosedur pengajuan pembiayaan syariah masih kurang. Hal tersebut disebabkan petani masih beranggapan bahwa pembiayaan syariah sama seperti pembiayaan konvensional, sebagian besar petani berpendidikan Sekolah Dasar dan pengalaman mengakses pembiayaan lebih banyak berasal dari bandar. Faktor-faktor yang berhubungan secara signifikan dengan pengetahuan petani mengenai prosedur pembiayaan syariah yaitu pendapatan, pengalaman mengakses pembiayaan, sumber informasi, dan jenis kelamin.
\end{abstract}

Kata kunci: Pembiayaan syariah, prosedur, pengetahuan petani

\section{ABSTRACT}

Pasirwangi subdistrict is one of the potato producing centers in Garut District. In carrying out the farming, farmers have faced various problems, one of which is capital. This is because farming potatoes requires a relatively large cost, so it requires financing other than private capital. The purpose of this study was to analyze the knowledge of potato farmers on the procedure to obtain sharia finance and factors related to the knowledge. This research used quantitative methods. Data were collected from 50 potato farmers in the Pasirwangi Subdistrict, Garut District. The data analysis method used gap analysis and ordinary least square. The result of this study shows that the farmers lacked knowledge on the procedure to obtain sharia finance. That was because most the farmers thought that sharia financing was similar with conventional financing, most farmers' education level were primary school and their experience in accessing financing was mostly from middlemen. Factors that had a significant influence on the procedure to obtain sharia finance were income, experience of accessing finance, sources of information, and gender.

Keywords: Sharia finance, procedures, farmers knowledge 


\section{PENGETAHUAN PETANI KENTANG TERHADAP PROSEDUR PEMBIAYAAN SYARIAH DI \\ KECAMATAN PASIRWANGI, KABUPATEN GARUT \\ Deviawati, Eliana Wulandari}

\section{PENDAHULUAN}

Pembiayaan memiliki peranan penting dalam pengembangan usahatani, salah satunya adalah usahatani kentang. Usahatani kentang membutuhkan biaya yang relatif besar, biaya yang dibutuhkan untuk usahatani kentang granola di Kabupaten Garut mencapai Rp92.655.773 per ha per musim (Basuki et al, 2020). Produksi kentang di Indonesia tersebar di berbagai provinsi dan kabupaten. Kabupaten Garut merupakan penghasil kentang terbesar di Jawa Barat dengan rata-rata produksi dari tahun 2015-2019 mencapai 169.915 ton (BPS, 2015-2019). Sentra produksi kentang di Kabupaten Garut tersebar di beberapa kecamatan, dimana penghasil kentang terbesar adalah Kecamatan Pasirwangi. Berdasarkan data Kabupaten Garut Dalam Angka tahun 2020, jumlah produksi kentang di Kecamatan Pasirwangi tahun 2019 mencapai 53.001 ton.

Permasalahan umum yang sering terjadi adalah permodalan. Menurut Ridlwan (2016), pertanian dengan skala kecil selalu memiliki masalah akses permodalan, hal tersebut disebabkan oleh petani tidak dapat memenuhi persyaratan dari lembaga keuangan sehingga tidak bankable. Kesulitan lain yang dihadapi oleh petani saat akan mengakses sumber pembiayaan adalah prosedur yang rumit, tidak memiliki jaminan serta tingginya suku bunga yang harus dipenuhi menjadi penyebab rendahnya akses petani terhadap sumber pembiayaan (Akram et al, 2008). Sehingga petani lebih memilih sumber pembiayaan informal dengan prosedur yang tidak rumit, bersifat fleksibel, serta kepercayaan dilihat dari saling mengenal (Haryanti dan Wulandari, 2018). Oleh karena itu diperlukan kontribusi perbankan syariah dalam pembiayaan sektor pertanian (Asaad, 2011). Perbankan syariah dengan sistem bagi hasil, merupakan solusi untuk permasalahan petani yang keberatan dengan tingginya suku bunga bank konvensional (Ridlwan, 2016).

Namun kenyataannya, rata-rata jumlah pembiayaan yang disalurkan oleh bank umum syariah dan unit usaha syariah dari Januari 2016 - Januari 2020 mencapai Rp. 304.922 miliar (statistik perbankan syariah, Januari 2016 - Januari 2020). Pembiayaan yang disalurkan untuk sektor pertanian, perburuan, dan kehutanan masih relatif rendah jika dibandingkan dengan sektor usaha lainnya. Salah satu penyebab rendahnya penyaluran pembiayaan ke sektor pertanian adalah sektor pertanian 
memiliki risiko yang tinggi dan sulitnya menerapkan akad untuk pinjaman modal tersebut. Hal tersebut menyebabkan petani masih kesulitan untuk mendapatkan akses pembiayaan (Ridlwan, 2016).

Dalam kegiatan usahatani kentang, petani kentang di Kecamatan Pasirwangi mengalami permasalahan akan akses permodalan. Sebagian besar petani mengakses pembiayaan dari bandar, karena dirasa tidak memerlukan prosedur yang rumit jika dibandingkan dengan pinjaman dari lembaga keuangan formal.

Fakta di lapangan menunjukkan bahwa, hanya beberapa orang yang sudah mengetahui prosedur pembiayaan syariah. Berdasarkan hal tersebut maka perlu dilakukan pengkajian mengenai pengetahuan petani kentang terhadap prosedur untuk mendapatkan pembiayaan syariah. Tujuan dilakukannya penelitian ini adalah untuk menganalisis tingkat pengetahuan petani kentang terhadap prosedur untuk mendapatkan pembiayaan syariah.

\section{METODE PENELITIAN}

Penelitian dilakukan di Desa Barusari dan Desa Padaawas Kecamatan Pasirwangi, Kabupaten Garut. Kedua desa tersebut merupakan penghasil kentang terbesar di Kecamatan Pasirwangi. Penelitian ini menggunakan desain kuantitatif dengan metode survei dari 50 petani.

Analisis data menggunakan gap analysis dan Ordinary Least Square (OLS). Analisis beda dapat digunakan dalam suatu organisasi, untuk menentukan pengetahuan yang dibutuhkan dan pengetahuan yang tersedia (Setiarso et al, 2009). Penskoran didasarkan pada tingkat kesesuaian. Tingkat kesesuaian merupakan hasil perbandingan nilai kinerja dengan nilai tingkat harapan (Supranto, 2001).

Nilai pengolahan data dari berbagai prosedur yang diketahui oleh petani kemudian diskorkan. Penskoran ini dilakukan dengan cara mencocokkan jawaban petani untuk pertanyaan tentang prosedur untuk memperoleh pembiayaan. Selanjutnya pemberian skor pengetahuan akan disesuaikan dengan jawaban dari penyedia pembiayaan. Skor 1 akan diberikan jika petani mampu menjawab dengan benar 22 pertanyaan mengenai prosedur untuk mendapatkan pembiayaan dari perbankan syariah. Langkah selanjutnya jika petani menjawab benar 1 dari 22 pertanyaan akan diberi skor 0,045, jawaban $2(0,09), 3(0,135)$, dan seterusnya sampai dengan 22 (1). 
Menurut Arikunto (2010) pengukuran tingkat pengetahuan adalah:

1. Pengetahuan yang baik, dapat menjawab dengan benar 76-100\% dari total pertanyaan,

2. Pengetahuan yang cukup, mampu menjawab dengan benar 56-75\% dari total pertanyaan, dan

3. Pengetahuan kurang, bisa menjawab $<56 \%$ dari total pertanyaan.

Dalam penelitian ini penggunaan OLS bertujuan untuk menganalisis keterkaitan antara variabel dependen $\mathrm{Yj}$ (pengetahuan petani terhadap prosedur untuk mendapatkan pembiayaan syariah) dengan variabel independen yang dilibatkan, yaitu usia, jenis kelamin, pendidikan, pendapatan, pengalaman dalam mendapatkan pembiayaan, pengalaman berusahatani, dan sumber informasi. Persamaan uji OLS sebagai berikut:

$y j=\alpha+\beta 1$ usia $+\beta 2$ jenis kelamin $+\beta 3$ pendidikan $+\beta 4$ pendapatan $+\beta 5$ akses pembiayaan $+\beta 6$ pengalaman dalam berusahatani $+\beta 7$ sumber informasi $+\varepsilon$

Keterangan:

$y_{-} \mathrm{j}:$ Pengetahuan petani terhadap prosedur untuk mendapatkan pembiayaan dari sumber $j$

$\alpha \quad$ : Konstanta

$\quad \beta 0 \quad$ : Koefisien regresi
X1 : Usia petani (tahun)

X2 : Jenis kelamin petani (1: lakilaki; 0:perempuan)

X3 : Pendidikan petani (0: tidak tamat SD; 1: SD; 2: SMP; 3:SMA; dan

$$
\text { 4: Universitas) }
$$

X4 : Pendapatan (Rp)

X5 : Pengalaman petani dalam mendapatkan pembiayaan syariah (1: pernah mendapatkan pembiayaan syariah; 0: tidak pernah mendapatkan pembiayaan syariah)

X6 : Pengalaman petani dalam berusahatani (tahun)

X7 : Sumber informasi (1: mendapatkan sumber informasi mengenai pembiayaan syariah; 0 : tidak mendapatkan sumber informasi mengenai pembiayaan syariah)

$\varepsilon \quad:$ Standard error

\section{HASIL DAN PEMBAHASAN}

\section{Karakteristik Petani}

Karakteristik petani dalam penelitian ini meliputi usia, jenis kelamin, tingkat pendidikan, pendapatan, akses terhadap sumber pembiayaan, pengalaman usahatani dan sumber informasi. Mayoritas petani berusia 45 tahun dan jenis kelamin laki-laki. Tingkat 
pendidikan mayoritas petani adalah Sekolah Dasar. Pendapatan rata-rata usahatani adalah Rp5.000.000 per bulan. Sumber pembiayaan yang paling banyak diakses oleh petani adalah pedagang atau bandar. Rata-rata pengalaman usahatani 17 tahun dan sumber informasi banyak didapatkan dari tetangga/saudara/kerabat secara mouth to mouth.

\section{Pengetahuan Petani Kentang Terhadap Prosedur untuk Mengakses Pembiayaan Syariah}

Pengetahuan merupakan hasil dari proses pembelajaran untuk menjadi tahu dari awalnya tidak tahu (Solikhati, 2012). Pengetahuan menjadi salah satu hal terpenting yang harus dimiliki oleh petani kentang untuk mendapatkan pembiayaan syariah. Salah satu pengetahuan yang harus dimiliki yaitu cara mendapatkan pembiayaan.

Petani pada umumnya sudah mengetahui mengenai pembiayaan syariah, namun hanya pengetahuan secara umum. Pembiayaan syariah bagi petani belum familiar yang disebabkan oleh ketersediaan pembiayaan syariah yang masih minim di Kecamatan Pasirwangi. Berdasarkan hasil penelitian, ketersediaan pembiayaan syariah di Kecamatan Pasirwangi terdiri atas BMT yakni BMT One Asgar Pasirwangi serta adanya program Komunitas Usaha Mikro Muamalat Berbasis Masjid (KUM3). Pengetahuan petani terhadap prosedur pembiayaan syariah terlihat pada Tabel 1 .

Tabel 1. Pengetahuan Petani Terhadap Prosedur Pembiayaan Syariah

\begin{tabular}{lc}
\hline $\begin{array}{c}\text { Akses ke pembiayaan } \\
\text { syariah }\end{array}$ & $\begin{array}{c}\text { Skor } \\
\text { pengetahuan }\end{array}$ \\
\hline Ya & 0,76 \\
Tidak & 0,52 \\
Rata-rata & 0,54 \\
\hline Sumber: Analisis Data Primer $(2020)$
\end{tabular}

Sumber: Analisis Data Primer (2020)

Berdasarkan Tabel 1 bahwa ratarata pengetahuan petani kentang terhadap prosedur pembiayaan syariah adalah 0,54 . Berdasarkan kategorisasi tingkat pengetahuan menurut Arikunto (2010), hal ini menunjukkan bahwa pengetahuan petani kentang tentang prosedur pembiayaan syariah masih kurang. Sebagian besar petani sudah mengetahui mengenai pembiayaan syariah, namun hanya pengetahuan secara umum. Akan tetapi, pengetahuan mengenai prosedur, produk-produk yang ditawarkan, skimskim pembiayaan, dan lain-lainnya petani belum mengetahui. Kurangnya pemahaman petani mengenai pembiayaan tentunya mengurangi minat petani untuk mengakses pembiayaan syariah. Pembiayaan syariah cukup menguntungkan bagi petani karena tidak menggunakan sistem bunga. Namun, petani masih beranggapan bahwa perbankan syariah sama seperti 


\section{PENGETAHUAN PETANI KENTANG TERHADAP PROSEDUR PEMBIAYAAN SYARIAH DI \\ KECAMATAN PASIRWANGI, KABUPATEN GARUT \\ Deviawati, Eliana Wulandari}

perbankan konvensional, menggunakan sistem bunga. Sehingga pengetahuan petani mengenai prosedur pembiayaan syariah masih kurang. Selain itu, karena tingkat pendidikan sebagian besar petani adalah sekolah dasar dan pengalaman mereka dalam mengakses pembiayaan sebagian besar dari bandar menyebabkan kurang informasi mengenai pembiayaan syariah. Selain itu, rendahnya tingkat pendidikan formal terakhir petani dapat menjadi salah satu penyebabnya. Tingkat pendidikan mempengaruhi keputusan seseorang untuk mengakses pembiayaan (Remund, 2010). Dalam hal ini, mayoritas petani mempunyai tingkat pendidikan yang rendah. Rendahnya tingkat pendidikan petani akan membatasi kemampuan dalam memahami prosedur pembiayaan syariah.

Petani yang tidak mengakses pembiayaan syariah memiliki skor pengetahuan yang rendah yaitu 0,52 . Hal tersebut, disebabkan oleh kurangnya pengalaman petani dalam mengakses pembiayaan syariah. Menurut Prasiwi dan Wulandari (2018), perbedaan pengalaman dalam mengakses pembiayaan akan memberikan pengaruh yang berbeda-beda, tergantung pada pernah atau tidaknya petani mendapatkan pembiayaan dari sumber pembiayaan tersebut.

\section{Faktor-Faktor yang Berkaitan dengan Pengetahuan Petani Kentang Terhadap Prosedur untuk Mendapatkan Pembiayaan Syariah}

Faktor-faktor yang berkaitan dengan pengetahuan petani kentang terhadap prosedur untuk mendapatkan pembiayaan syariah dapat dilihat dari hasil uji regesi pada Tabel 2.

Tabel 2. Hasil OLS Pengetahuan Petani Kentang Terhadap Prosedur untuk Mendapatkan Pembiayaan Syariah

\begin{tabular}{l|rrc}
\hline Variabel & Coef & $\mathbf{t}$ & $\mathbf{P}>|\mathbf{t}|$ \\
\hline Usia & $-0,000$ & $-0,17$ & 0,869 \\
Jenis kelamin & 0,127 & 1,93 & 0.060 \\
Pendidikan & 0,000 & 0,01 & 0,994 \\
Pendapatan & $1.81 \mathrm{e}$ & 2,77 & 0,008 \\
Pengalaman & & & \\
mendapatkan & 0,203 & 2,42 & 0,020 \\
pembiayaan syariah & & & \\
Pengalaman & $-0,000$ & $-0,46$ & 0,646 \\
berusahatani & 0,105 & 2,27 & 0,028 \\
Sumber informasi & 0,277 & 2,10 & 0,042 \\
Konstanta &
\end{tabular}

Sumber: Analisis Data Primer (2020)

Berdasarkan hasil uji OLS pada Tabel 2, maka diperoleh persamaan model regresi sebagai berikut.

$$
\begin{aligned}
& \mathrm{Y}=0,277-0,00 \mathrm{X} 1+0,127 \mathrm{X} 2+0,000 \mathrm{X} 3 \\
& +1.81 \mathrm{eX} 4+0,203 \mathrm{X} 5-0,000 \mathrm{X} 6+ \\
& 0,105 \mathrm{X} 7
\end{aligned}
$$

Variabel pendapatan berkaitan secara signifikan dan positif terhadap pengetahuan mengenai prosedur pembiayaan syariah. Pendapatan dalam penelitian ini, yaitu pendapatan petani 
selama satu bulan. Berdasarkan teori, semakin tinggi pendapatan seseorang maka semakin tinggi pula pengetahuannya, karena orang yang berpendapatan tinggi memiliki fasilitas untuk mendapatkan pengetahuan yang lebih baik (Budiman dan Riyanto, 2013). Menurut Rahayu (2016), pengangsuran kredit dan pemilihan produk kredit dipengaruhi oleh besarnya pendapatan. Petani dengan pendapatan tetap akan lebih memilih sistem pengembalian kredit secara bulanan namun, petani dengan pendapatan tidak tetap lebih memilih sistem pengembalian secara musiman saat masa panen. Selain itu, semakin besar pendapatan petani maka semakin besar peluang petani untuk mengakses LKM BMT. Berdasarkan hal tersebut, maka peluang petani terhadap sumber pembiayaan syariah besar. Hal tersebut juga akan menambah pengetahuan petani mengenai prosedur pembiayaan.

Variabel pengalaman dalam mengakses pembiayaan berkaitan secara signifikan dan positif terhadap pengetahuan mengenai prosedur pembiayaan syariah. Pengalaman merupakan sumber pengetahuan, dimana pengalaman juga dapat menambah pengetahuan. Semakin banyak pengalaman mendapatkan pembiayaan maka semakin tinggi pula pengetahuan yang dimiliki. Sejalan dengan penelitian yang dilakukan oleh Haryanti dan Wulandari (2018), bahwa pengalaman mengakses pembiayaan berpengaruh signifikan terhadap pengetahuan mengenai prosedur untuk mendapatkan pembiayaan. Artinya semakin banyak pengalaman mengakses pembiayaan yang dimiliki oleh petani maka secara tidak langsung akan meningkatkan pengetahuan petani mengenai prosedur untuk mendapatkan pembiayaan syariah.

Variabel sumber informasi berkaitan secara signifikan dan positif terhadap pengetahuan mengenai prosedur pembiayaan syariah. Artinya semakin banyak sumber informasi mengenai prosedur pembiayaan yang didapatkan semakin tinggi pengetahuan petani. Hal tersebut sejalan dengan penelitian terdahulu oleh Haryanti dan Wulandari (2018), bahwa sumber informasi berpengaruh terhadap pengetahuan petani mengenai prosedur untuk mendapatkan pembiayaan dari bank. Hasil penelitian menurut Supanggih dan Widodo (2013) mengenai aksesibilitas petani terhadap lembaga keuangan menjelaskan bahwa kurangnya sumber informasi mengenai lembaga keuangan menjadi salah satu 


\section{PENGETAHUAN PETANI KENTANG TERHADAP PROSEDUR PEMBIAYAAN SYARIAH DI \\ KECAMATAN PASIRWANGI, KABUPATEN GARUT \\ Deviawati, Eliana Wulandari}

permasalahan yang dihadapi petani saat akan mengakses pembiayaan serta petani merasa bahwa prosedur atau proses yang ada pada lembaga keuangan formal dirasa rumit, memerlukan biaya yang besar, dan ribet. Sehingga petani lebih banyak mengakses pembiayaan non formal. Menurut Indrawati (2014), bahwa sosialisasi yang dilakukan oleh pihak perbankan tidak berpengaruh terhadap permintaan kredit ke bank syariah, pada kenyataannya petani tertarik namun petani masih belum memahami mengenai mekanisme dan produk perbankan syariah

Variabel jenis kelamin berkaitan secara signifikan dan positif terhadap pengetahuan petani mengenai prosedur pembiayaan syariah. Menurut Prasiwi dan Wulandari (2018), bahwa wanita cenderung kurang fleksibel dalam hal pinjam meminjam modal, wanita lebih cenderung menggunakan harta pribadi atau tabungan untuk modal usahanya. Selain itu, menurut Widodo et al (2009), bahwa perempuan (istri) tidak memiliki akses untuk mendapatkan kredit dari koperasi maupun perbankan. Laki-laki (suami) mendominasi dalam pengambilan keputusan, pandangan yang berkembang di masyarakat adalah bahwa perempuan lebih banyak mengerti masalah rumah tangga (Widodo et al, 2009). Dengan demikian, petani yang memiliki akses yang lebih terhadap sumber pembiayaan adalah laki-laki, yang dapat menyebabkan bertambahnya pengetahuan petani mengenai pembiayaan syariah.

\section{KESIMPULAN DAN SARAN}

Pengetahuan petani kentang terhadap prosedur untuk mendapatkan pembiayaan syariah tergolong masih kurang. Hal ini disebabkan anggapan petani mengenai pembiayaan syariah bahwa perbankan syariah sama seperti perbankan konvensional, rendahnya tingkat pendidikan petani serta pengalaman mengakses pembiayaan syariah yang rendah. Faktor-faktor yang berkaitan secara signifikan dengan pengetahuan petani mengenai prosedur pembiayaan syariah yaitu pendapatan, pengalaman mengakses pembiayaan, sumber informasi dan jenis kelamin.

Saran untuk meningkatkan pengetahuan petani terhadap prosedur untuk mendapatkan pembiayaan adalah petani dapat lebih memanfaatkan sumber informasi untuk menggali informasi mengenai prosedur apa saja yang diperlukan untuk mendapatkan pembiayaan syariah. Untuk penyedia pembiayaan syariah, diharapkan lebih 
banyak memberikan informasi atau mensosialisasikan prosedur pembiayaan syariah kepada petani dengan pendekatan kelompok, sehingga petani lebih mengetahui prosedur tersebut dan menambah kesempatan petani untuk mendapatkan pembiayaan.

\section{DAFTAR PUSTAKA}

Akram W, Hussain Z, Sial MH, \& Hussain I. (2008). Agricultural credit constraints and borrowing behavior of farmers in Rura Punjab. European Jof Scien Research. 23(2):294-304

Arikunto, S. (2010). Prosedur Penelitian: Suatu Pendekatan Praktik. Jakarta: Rineka Cipta.

Asaad, M. (2011). Peningkatan Peranan Perbankan Syariah Untuk Pembiayaan Usaha Pertanian. MIQOT: Jurnal Ilmuilmu Keislaman, 35(1).

Badan Pusat Statistik. (2016 - 2020). Provinsi Jawa Barat Dalam Angka Tahun 2016 - 2020. BPS Provinsi Jawa Barat.

Badan Pusat Statistik. (2019). Statistik Indonesia 2019. BPS Indonesia.

Badan Pusat Statistik. (2020). Kabupaten Garut Dalam Angka tahun 2020. BPS Kabupaten Garut.

Basuki, R. S., Khaririyatun, N., Sembiring, A., Nurmalinda, N., \& Arshanti, I. W. (2020). Studi Adopsi Benih Kentang Bebas Virus Varietas Granola L. dari Balai Penelitian Tanaman Sayuran di Kabupaten Garut, Jawa Barat. Jurnal Hortikultura, 29(2), 241. https://doi.org/10.21082/jhort.v29n 2.2019.p241-256.

Budiman dan Riyanto A (2013). Kapita Selekta Kuesioner Pengetahuan dan
Sikap dalam Penelitian Kesehatan. Jakarta : Salemba

Haryanti, S., \& Wulandari, E. (2018). Pengetahuan Petani Pisang Terhadap Prosedur Untuk Mendapatkan Pembiayaan. (Kasus di Kelompok Tani Sagara, Desa Kanoman, Kecamatan Cibeber Kabupaten Cianjur). Agroland: Jurnal Ilmu-ilmu Pertanian, 25(3), 187-196.

Indrawati, H. (2014). Determinan Permintaan Pembiayaan Syariah Determinan Permintaan Petani Kelapa Sawit terhadap Pembiayaan Syariah. Sosiohumaniora, 16(2), 137-142.

Otoritas Jasa Keuangan (2016-2020). Statistik Perbankan Syariah. OJK

Prasiwi, A., \& Wulandari, E. (2018). Persepsi Petani Terhadap SyaratSyarat Penting Untuk Mendapatkan Pembiayaan. Agroland: Jurnal Ilmu-ilmu Pertanian, 25(1), 1-11.

Rahayu, L. (2016). Aksesibilitas petani bawang merah terhadap lembaga keuangan mikro sebagai sumber pembiayaan. AGRARIS: Journal of Agribusiness and Rural Development Research, 1(1), 5260.

Remund, D. L. (2010). Financial literacy explicated: The case for a clearer definition in an increasingly complex economy. Journal of Consumer Affairs, 44(2), 276-295. https://doi.org/10.1111/j.17456606.2010.01169.x.

Ridlwan, A. A. (2016). Implementasi Akad Muzara'ah pada Bank Syariah: Alternatif Akses Permodalan Sektor Pertanian. IQTISHODUNA: Jurnal Ekonomi Islam, 5(1), 34-48.

Setiarso, B, N. H Triyono, H. Bagyo. (2009). Penerapan Knowledge Management pada Organisasi. Yogyakarta : Graha Ilmu. 
Solikhati, A. (2012). Jenis-jenis Pengetahuan. Artikel: Surabaya.

Supanggih, D., \& Widodo, S. (2013). Aksesibilitas petani terhadap lembaga keuangan (studi kasus pada petani di desa sidodadi kecamatan Sukosewu kabupaten Bojonegoro). Agriekonomika, 2(2), 163-173.
Supranto, J. (2001). Pengukuran Tingkat Kepuasan Pelanggan: Untuk Menaikkan Pangsa Pasar. Jakarta : Rineka Cipta

Widodo, S., \& Trunojoyo, J. A. F. P. U. (2009). Analisis peran perempuan dalam usahatani tembakau. Analysis of the role of women in the tobacco farming. Embryo, 6(2), 148-153. 